\title{
Rethinking the learning space at work and beyond: The achievement of agency across the boundaries of work-related spaces and environments
}

\author{
Natasha Kersh ${ }^{1}$
}

Published online: 23 January 2016

(c) The Author(s) 2016. This article is published with open access at Springerlink.com

\begin{abstract}
This paper focuses on the notion of the learning space at work and discusses the extent to which its different configurations allow employees to exercise personal agency within a range of learning spaces. Although the learning space at work is already the subject of extensive research, the continuous development of the learning society and the development of new types of working spaces calls for further research to advance our knowledge and understanding of the ways that individuals exercise agency and learn in the workplace. Research findings suggest that the current perception of workplace learning is strongly related to the notion of the learning space, in which individuals and teams work, learn and develop their skills. The perception of the workplace as a site only for work-specific training is gradually changing, as workplaces are now acknowledged as sites for learning in various configurations, and as contributing to the personal development and social engagement of employees. This paper argues that personal agency is constructed in the workplace, and this process involves active interrelations between agency and three dimensions of the workplace (individual, spatial and organisational), identified through both empirical and theoretical research. The discussion is supported by data from two research projects on workplace learning in the United Kingdom. This paper thus considers how different configurations of the learning space and the boundaries between a range of work-related spaces facilitate the achievement of personal agency.
\end{abstract}

Keywords Learning spaces · Motivation - Workplace learning · Boundary crossing $\cdot$ Personal agency

Natasha Kersh

n.kersh@ioe.ac.uk

1 UCL Institute of Education, University College London, London, UK 
Résumé Repenser l'espace d'apprentissage à l'intérieur et à l'extérieur du milieu professionnel : réaliser l'agentivité à travers des limites des espaces et environnements de travail - Cet article aborde la notion d'espace d'apprentissage au travail et analyse dans quelle mesure ses diverses configurations permettent aux employés d'exercer une agentivité individuelle dans des espaces d'apprentissage variés. Bien que ces derniers aient déjà fait l'objet d'une recherche abondante, l'évolution constante de la société apprenante et l'apparition de nouvelles formes d'espaces de travail appellent à en approfondir l'étude, pour élargir nos connaissances et conceptions sur les façons dont les individus exercent l'agentivité et apprennent en milieu professionnel. Les résultats scientifiques indiquent que la perception actuelle de l'apprentissage sur le lieu de travail est fortement liée à la notion d'espace d'apprentissage dans lequel individus et équipes travaillent, apprennent et perfectionnent leurs compétences. La perception selon laquelle le milieu professionnel permet uniquement les formations liées au travail évolue progressivement, ce milieu étant aujourd'hui considéré comme ouvert à l'apprentissage dans des configurations variées, et contribuant au développement personnel et à l'engagement social des employés. L'auteure avance que l'agentivité individuelle se construit dans l'environnement professionnel, et que ce processus implique des interrelations actives entre l'agentivité et les trois dimensions du lieu de travail identifiées par la recherche tant empirique que théorique (individuelle, spatiale et organisationnelle). L'analyse est étayée par les données issues de deux études menées sur l'apprentissage en milieu professionnel au Royaume-Uni de Grande-Bretagne et d'Irlande $\mathrm{du}$ Nord. L'auteure examine ainsi comment les espaces d'apprentissage dans diverses configurations et les frontières entre un grand nombre d'espaces professionnels facilitent la réalisation de l'agentivité individuelle.

\section{Introduction}

The notion of the learning space at work and the ways it facilitates individual engagement and influences perceptions of knowledge and learning at work has been reconceptualised in the last decade, in response to the changing requirements of contemporary economies and, more specifically, workplaces (Kolb and Kolb 2005; Malloch et al. 2011; Evans and Kersh 2014). The relationships between spaces, learning and individual identities have been considered from a range of perspectives and within various disciplines. The notion of space has its roots in the discipline of geography, where it is traditionally considered as a fundamental concept (e.g. Burrough 1996; Gatrell 1991; Pidwirny 2006). In social science research, the significance of space as a concept has been brought to our attention by sociologists who have drawn attention to its relationships and interactions with other concepts such as, for example, individual knowledge and power (e.g. Bronfenbrenner 1977; Foucault 1980; Soja 2002; Goffman 1990). Increasingly within social science research, space is regarded as an influential concept with respect to learning and social relationships. Consideration of the ways spaces are constructed and interpreted through social processes contributes to an understanding of how 
individuals navigate different contexts and environments (Brooks et al. 2012; Evans et al. 2006).

This paper argues that the learning space at work plays an important role in facilitating or undermining personal agency, and specifically looks at how agency is configured through three dimensions of the learning space. I begin by considering the notion of space and its interrelationships with learning in the workplace. I then consider how individual learning processes are configured through three dimensions that relate to the development of agency and engagement within and at the boundaries of workplace learning; namely, the individual (role of an individual), spatial (the potential utility of a space) and organisational (opportunities provided by an organisational context) dimensions. Using data from two research projects, undertaken across a range of occupational sectors in different UK workplaces (including, for example, the fire and rescue services, and the engineering and social care sectors), this paper considers the ways in which learners/employees gather different kinds of knowledge within the boundary spaces that emerge from various practices and experiences. The final part reflects on the implications for individual agency.

\section{The changing nature of the learning space at work and individual learning across the boundaries of spaces}

Socially constructed learning contexts have been a key focus of educational debate over the past twenty years (e.g., Evans et al. 2006; Kersh et al. 2012; Edwards et al. 2004; Solomon et al. 2006). Complex relationships between workplaces and individuals in the modern, globalised world have been the subject of research interests in numerous international publications (e.g., Aspin et al. 2012; Malloch et al. 2011; Evans et al. 2006; Rainbird et al. 2004; Boud 2006; Guile 2010). The workplace as a learning space that may facilitate personal agency and motivation has also been recognised as a significant context associated with individual attitudes and aspirations (Eraut and Hirsh 2007; Hodkinson et al. 2004; Ecclestone et al. 2009).

The role of the workplace and the characteristics of learning within a specific working space have been the subject of a significant body of research literature (e.g., Edwards et al. 2004; Evans et al. 2006; Malloch et al. 2011), which also emphasises interdependencies with individual motivation, experience and agency. Specifically, such interdependencies are facilitated by the significance of individual biography (Hodkinson et al. 2004), individual disposition in relation to workplace opportunities (Evans et al. 2004 and 2006), and the impact of individual perspectives on knowledge and learning at work (Eraut 2004). What employees learn in the workplace and in experiences beyond the workplace contributes to their skills and personal development. What is more, personal workspaces enhance effectiveness, creativity and social practices within constantly changing contemporary workplaces (Kohlegger et al. 2013).

Research seeking to understand the multifaceted relationships between workplace spaces and an individual's exercise of learning agency have been informed by 
a range of theoretical approaches, including situated learning (Lave and Wenger 1998), activity theory (Engeström et al. 1995) and social ecology (Evans, Waite and Kersh 2011). These theoretical approaches provide useful insights into the ways individuals can develop through a variety of work-based learning experiences. The workplace as a context for learning has also been discussed specifically in terms of the way it may facilitate or restrict adults' learning opportunities and life chances. Karen Evans et al. (2006), for example, point to a strong relationship between opportunities provided by the workplace and the nature of the environment at work, which influences the way adults learn in, for and through the workplace. As conceptualised in Evans et al. (ibid.), "learning in, for and through the workplace" provides a range of opportunities for exercising individual agency within the workplace and related activities. In this interpretation, learning at work, which is understood as more than employment for remuneration (Malloch et al. 2011), allows us to consider individual dispositions and motivations in relation to three key terms: work, place and learning (ibid.). My previous research (e.g. Kersh et al. 2012; Evans and Kersh 2014) has drawn on these key terms which together constitute the concept of workplace learning, looking specifically at their structure, meaning and potential utility, and further considering configurations of learning at work through individual engagement and considering the role of individuals and employers in the contemporary workplace learning space.

The learning space as a concept can be considered and conceptualised in its different configurations (Evans et al. 2006; Solomon et al. 2006; Kersh et al. 2011). Physical space, such as a classroom or any other form of teaching space, is one interpretation of the learning space, which is traditionally associated with conventional schooling. Additionally, the learning space can refer to a space where learning occurs unintentionally and incidentally; this type of space is not restricted to a classroom or lecture room. The development of experiential learning theories (Boud et al. 1985; Kolb 1984; Kolb and Kolb 2005) has advanced our understanding of the ways that learning informally in a range of informal learning spaces or across their boundaries has facilitated individual engagement and agency. The work of Michael Eraut (2004) and Evans et al. (2006), for example, has demonstrated how employees learn from each other's experiences informally or experientially in a variety of informal learning spaces at work. The expansion of modern technologies has resulted in the development of virtual learning spaces that change and merge the boundaries between spaces, making them more flexible and mobile. Additionally, learning spaces can be perceived as a combination or overlap of a range of components, including physical space, learning contexts and environments, formal/ informal learning, and virtual learning. Contemporary trends in economic, political and educational developments have somewhat blurred the boundaries between the spaces in which learning, work and leisure occur. The term "learning space" is used in this paper to consider all the interpretations of the learning space outlined above. The related terms "environments" and "contexts" are employed in this paper in order to consider different configurations and meanings of the learning space, where spaces are recognised and perceived as learning contexts and environments.

In this paper, the notion of "boundaries" has been conceptualised as a type of "space" facilitating the potential for learning (Harris and Ramos 2012; Edwards 
2011) and providing opportunities for individual engagement (Evans et al. 2006). Learning through boundary-crossing within and between the contexts of education, work and other related contexts has been a subject of interest in a number of national and international studies (Guile 2010; Harreveld and Singh 2009; TuomiGrohn and Engeström 2003). The notion of boundary-crossing where boundaries are perceived as spaces with potential for learning (Harris and Ramos 2012) has also been considered through various theoretical lenses. Arthur Bakker et al. (2011) note that in sociocultural and cultural-historical theories, challenges in communication between practices are often conceptualised in terms of boundaries. Activity theory (Engeström et al. 1997) has been employed as a theoretical lens to analyse workplaces and their boundaries as characterised by their own object of activity. Evans, Waite and Kersh (2011) look at workplace contexts and spaces through the lens of social ecology theories. Drawing on this theoretical approach, my earlier research (Kersh et al. 2012) further considers the interplay between learning and working spaces, where boundaries and spaces are multifaceted and multidimensional. In order to better understand learning in changing spaces and boundary crossing, this paper draws on social ecology theories, which are concerned with the study of people in an environment or space, and the interrelations between them (Evans, Waite and Kersh 2011). The concept of "boundary crossing" contributes to an understanding of learning at work and the ways in which learners acquire and use their knowledge and skills across different contexts.

In exploring the notion of space, social sciences research largely focuses on the ways in which space is constructed through social processes (Brooks et al. 2012). The issues of recognising spaces as learning contexts and the boundaries between a range of contexts have received much attention in the educational debate of the past twenty years. A significant body of research literature (e.g., Edwards et al. 2004; Evans et al. 2006; Malloch et al. 2011) draws attention to the meaning of the workplace context and the distinctive features associated with learning within workrelated spaces and contexts where workplace spaces are characterised as both work and learning spaces. This duality presupposes an interplay between learning and working spaces (e.g., the college and the workplace) where the somewhat blurred boundaries are multifaceted and multidimensional. Within these boundaries, learners' personal working and learning spaces enhance their effectiveness, creativity and social practices, as they acquire, use and apply a range of skills across different contexts, within the boundaries of constantly changing contemporary spaces (Kohlegger et al. 2013). The concept of "boundary crossing" could, therefore, be employed to illuminate movements of learners between different learning spaces, specifically drawing attention to learning across contexts (Harris and Ramos 2012). In such an interpretation, contexts play an important part in knowledge creation and development. For knowledge and skills acquired and used in one context to be applied in another context, they have to be transferred in various ways which simultaneously engage with and change those practices, traditions and experiences (Evans et al. 2006). As further argued by Sanne Akkerman and Arthur Bakker (2011), boundary crossing and knowledge transfer raise two important issues. One is that boundaries are an important condition for learning because they support and develop cultural traditions and human 
understanding. Another concerns the role of educational institutions and workplaces in supporting people to learn at the boundaries of social practice. In this vein, Michael Young et al. (2003) draw our attention to a link between the concept of "learning through boundary crossing" within and between the contexts of education and work, and the development of "vocational education and its practices". Such boundaries can be crossed by people, by objects and by interactions between actors of different practices (Akkerman and Bakker 2011).

Drawing on data from two research projects, undertaken in the UK between 2009 and 2014, this paper considers the interpretations and implications of boundary crossing in the workplace across three significant dimensions: individual, spatial and organisational. The "individual dimension" refers to the role of individual learners, their motivations and attitudes towards gathering and transferring across contexts different kinds of knowledge and skills. The "spatial dimension" refers to affordances ${ }^{1}$ and opportunities provided by different kinds of spaces and the extent to which spatial associations and environments facilitate learning and knowledge transfer. Finally, the "organisational dimension" concerns affordances provided by organisational contexts between workplace and learning spaces (e.g., between the college and the company) and the role and degree of employers' involvement in making the process of boundary crossing and knowledge transfer meaningful and significant.

\section{Empirical research: methodology and data collection}

This paper draws on data from two research projects that investigated the ways employees acquire and use basic skills (such as literacy, numeracy and information technology) in the workplace. The first of these, the "Adult Basic Skills (Skills for Life) in the Workplace project" (2009-2012), funded by the Economic and Social Research Council (ESRC), aimed to assess the effects on individuals and organisations of engagement in workplace literacy, numeracy and "English for Speakers of Other Languages" (ESOL) programmes. Data collection instruments included semi-structured interviews with learners, tutors and managers in organisations engaged with Skills for Life (SFL) workplace training. In order to explore affordances and opportunities provided by different kinds of spaces, this paper draws on data collected as part of the ESRC project, including interviews with 15 tutors, 14 managers and 20 employees who took part in SFL courses in the workplace. ${ }^{2}$ The data from the project helped to provide insight into different types of learning spaces, the associations made with different learning environments by employees, and the ways in which various configurations of the learning space at work facilitate employees' personal skills and enhance learning outcomes.

\footnotetext{
1 The term "affordance" is used to denote action possibilities provided to the individual by spaces and environments (Gibson 1977, 1979), where perception of the environments results in some action or activity. The related term "opportunity" is employed to indicate a combination of circumstances which make it possible to do or achieve something and/or to facilitate individual chances and prospects.

2 This research was carried out under the auspices of the ESRC Research Centre: Learning and Life Chances in Knowledge Economies and Societies (LLAKES), award number: RES-594-28-0001.
} 
The second project, this paper is drawing on, the NRDC 'Impact of Poor English and Maths Skills on English Employers' project, was undertaken in 2014. ${ }^{3}$ It investigated literacy and numeracy skills acquisition in the workplace through indepth case studies of employers who provided basic skills training completed between September and December 2012. The project focused on longer-term outcomes of learning basic skills in the workplace, as the timescale meant that roughly one year had elapsed by the time the case studies were carried out. Within the context of this project, nine in-depth case studies were undertaken across different occupational sectors, and this paper will particularly draw on the case study of the fire and rescue service.

The data analysis, carried out with the assistance of the NVivo programme for both projects, ${ }^{4}$ involved employing thematic analysis to identify the major themes through the process of open coding, which is a way of categorising the text in order to establish a framework of themes, including individual, spatial and organisational dimensions.

The rationale for choosing these two projects to support the discussion in this paper was twofold: both projects were concerned with workplace learning and basics skills acquisition in the workplace, thus enabling the researchers to gain an insight into the workplace as a learning space and the way in which the skills employees learn enable them to cross the boundaries between a range of spaces; and both projects dealt with outcomes associated with learning basic skills in the workplace. However, while the first project (ESRC) considered immediate or parallel outcomes through semi-structured interviews undertaken at the time or shortly after employee engagement with basic skills courses, the second project (NRDC) allowed us to look at longer-term outcomes through an in-depth case study approach which involved both interviews and observation in selected workplaces.

The discussion below draws on both the empirical data from the two projects and theoretical research on learning through workplace spaces.

\section{Individual engagement through boundary crossing}

The interpretation of the role and centrality of personal agency is an increasingly recognised component of workplace learning research (Billett 2011). The consideration of the part played by individual agency, disposition and motivation has substantially advanced our understanding of the work-related process within and at the boundaries of spaces and environments. The current debate on workplace learning emphasises the significance of individual biography (e.g., Hodkinson et al. 2004; Hodkinson 1995), individual motivation in the workplace (Evans et al. 2006; Evans et al. 2004), and the interdependencies between individual attitudes and informal learning in the workplace (Eraut 2004). Individual expectations and

\footnotetext{
3 This research was carried under the auspices of the National Research and Development Centre (NRDC), at the UCL Institute of Education, as part of IPSOS Mori Employer Survey.

${ }^{4}$ NVivo is a software package designed for qualitative data analysis (QDA). It is especially suited for analysing rich text-based and/or multimedia information, e.g. in social sciences research.
} 
attitudes are therefore perceived as motivating factors which are strongly related to the process of identity construction in the workplace and beyond (Gnaur 2010). The individual perspective on knowledge and learning as well as individual experiences in the workplace, as argued by Michael Eraut (2004), contribute to shaping the ways in which learners experience their environments (either formally or informally) and avail of new learning opportunities. In this context, as noted by Stephen Billett (2011), participatory practices in the workplace constitute a means to understand individual participation and learning in the workplace and comprise a duality between the potential of the workplace and individual engagement (ibid.). The utility and affordances provided by a space or a boundary between spaces are fundamentally associated with the nature of the workplace context, which enhances the way individuals learn in, for and through the workplace (Evans et al. 2006). Learning in the workplace underpins the interplay between individual agency, learning space and affordances provided by workplace organisational structures. This interplay has been considered elsewhere (Evans, Waite and Kersh 2011) through the lens of social-ecological interdependencies, and in doing this, they draw attention to the ways individuals interact with spaces in which to exercise agency.

Transferring different types of knowledge and skills across spaces is one of the facets of the learning process which is related to individual engagement, responsibility and the exercise of agency. The concept of "boundary crossing" has been used to advance knowledge and understanding of the ways that learners acquire and use their knowledge and skills in different contexts (Young et al. 2003; Guile 2010; Akkerman and Bakker 2011).

Research indicates that individual dispositions and motivations play significant roles in learning through boundary crossing. Previous research (Kersh et al. 2012; Evans and Kersh 2014) suggests that significant factors related to learners' personalities, backgrounds and environments are associated with previous educational experiences and previous workplace experiences, as well as with their attitudes and dispositions. Research undertaken by Evans et al. (2006) indicates that the ways in which learners are able to employ skills and transfer them to their present workplace or learning environments may facilitate motivation and confidence. Transferring knowledge and skills from one space to another is also related to personal motivations and attitudes. Individual engagement and motivation to facilitate learning in different spaces, contexts and environments are considered among the most significant factors contributing to the process of boundary crossing (Kersh et al. 2012). Personal engagement in learning through boundary-crossing experiences and enhancing life chances through motivation and attitudes are strongly related to self-directed learning, and taking individual responsibility for learning in various contexts, both formal and informal.

Empirical research indicates that employees embrace opportunities to apply literacy, numeracy and IT skills acquired through workplace courses to "real-life situations at work". The findings suggest that workplaces increasingly demand from their employees high levels of literacy, numeracy and IT skills, expecting them to be able to cope with both traditional and online documentation and instruction materials. Literacy skills enable learners both to cross boundaries between different spaces and to combine different kinds of knowledge and skills. Individual 
motivations strongly relate to the potential utility and opportunities of a learning context or space. The research suggests that spatial associations may either undermine or facilitate learning attitudes.

Our data from the empirical research indicate the ways in which employees cross the boundaries between learning spaces (such as literacy and numeracy training courses) and their workplace spaces. Combining literacy and numeracy skills and practical experiences in the workplace enables learners to cross the boundaries between different spaces such as between academic learning (theory) and practical work. Our case study undertaken in the fire and rescue service (NRDC project) indicates that employees are now expected to be able to deal with a wider range of emergencies than fire, such as flooding, road rescue and terrorism. This involves using new skills and constantly updating theoretical and academic knowledge, including more advanced Maths skills:

A basic firefighter has to have a certain level of education, and capability of displaying a range of skills. No longer are they just smoke eaters. They are learning new things constantly. Being able to read, write and calculate is fundamentally important within the settings of the fire and rescue service. Staff are engaged in continuous workplace learning, from the time they start their employment. Employees need to have good maths and English skills (Extract from employer interview, NRDC project).

In the job roles in question, good maths skills are essential, and poor maths skills could result in serious consequences (e.g., health and safety, putting civilians at risk, etc.). Firefighting involves an understanding of what buildings are made of, how fire behaves, how smoke moves and what quantities of water are needed. These are basic elements which firefighters need to understand:

If you can't calculate properly, this means, for example, that you run out of water at a crucial time. Basic English and maths ensures that all the other technical elements are understood by the staff. A good example is putting foam on a chemical fire - firefighters need to be able to calculate how much is needed for a specific situation (Extract from employee interview, NRDC project).

Individual motivations play a crucial role in helping employees develop literacy and numeracy skills and draw on them in their workplace activities:

If we can do calculations, this means that we are confident in what we are doing for our job's roles, and we would like to achieve more and do our jobs properly. My job role involves constant calculations of various kinds. Lots would relate to working out building sizes, how much water is in the tank, how much fuel is used, etc. The knowledge of hydraulics is essential in his job role and this involves being comfortable with maths calculations. I give a simple example: the water tank, for example, is 1,000 litres. We need to know how long it will last. It's something you need to know, be able to assess whether it will be enough for a specific incident. Maths is with us every day. How much 
water is going to be used in 3 hours? I need to be able to work that out very quickly (Extract from employee interview, NRDC project).

Competence development in the workplace is associated with a range of motivations at the individual level. The data support the view that both academic and practical knowledge is acquired through personal motivation and engagement, where motivation could be further facilitated through appropriate pedagogical strategies. One such strategy is gradual release, as discussed by Evans, Guile and Harris (2009). This involves supporting employees in moving between learning, practice and workplace environments via the gradual, iterative transfer of responsibility from educator, trainer and supervisor to learner. The exercise of responsibility by employees is strongly shaped by attitudes, motivations and dispositions in particular ways in response to workplace affordances and challenges. Workplace affordances and the extent to which employees are motivated to embark on the learning opportunities available to them facilitate the mapping of skills across learning spaces.

Crossing the boundaries between learning and workplace spaces through theorypractice consolidation is also associated with another important dimension, which relates to the development and use of modern technologies in work-related learning spaces. Employers and workplace training providers use technology, such as videos, a Virtual Learning Environment (VLE) and portable devices, to provide demonstrations of practical skills which students can access. New technologies are used to strengthen the delivery of academic teaching combined with vocational practices, specifically through introducing a range of innovative approaches, which enable learners to respond to their individual learning needs and requirements. Virtual learning is delivered through a range of portable devices (such as mobile phones or touch-screen tablets), which enables the college to facilitate "anywhere, anytime" access to learning resources for students. Computer and information technology (IT) skills, therefore, play an important role in facilitating learners' motivations and opportunities for crossing the boundaries between theory and practice. One successful example, emphasised in the course of our fieldwork at one institution, is the range of activities offered by an E-learning Resource Centre, available to support employees, including those taking part in a Skills for Life course. The centre provides additional support to learners, facilitating their independence, motivation and self-learning skills:

They [employees] come to us [...] First of all, it's identified in conversations with their line managers what their job profile is and what are the key skills attached to that, and what do they have already that maps into that profile. And then it becomes clear from there "OK these are the areas that I need to focus on to help me be fully effective in that role". They then book in to meet with my team around what has come out of that personal development discussion and then we look to see, first of all, questioning around how they learned in the past, what works well for them. So we very much take it from the individual and what they are telling us. [In the] E-learning room, people will be doing self-directed learning, but the team are here to act as a mentor or 
coach for people around that as well (Extract from interview with E-learning centre manager, Skills for Life project).

Our interviews indicated that employees who had participated in the Skills for Life (literacy, numeracy and Information Technology) workplace courses often applied their literacy and numeracy skills in their family contexts (e.g., helping their children with school homework or better managing their family budgets). Such individual engagement and motivation enabled employees to develop and apply a range of skills acquired in the course of workplace literacy and numeracy programmes in their family environments, thus extending the learning space from the workplace to the home environment. Additionally, adult learners' activities and experiences outside their workplaces allow them to acquire a range of skills which can be used in their workplace and learning environment. Our case studies undertaken within the health and social care sectors showed that a range of personal experiences in a range of spaces, such as family contexts (e.g., looking after an elderly relative at home or bringing up children) enabled employees to develop valuable skills such as patience, time-management and problem-solving. Our respondents indicated that they had successfully utilised these skills in their workplace environment (care homes), and this suggests that employees' concurrent environments and circumstances (e.g., family life) play an important role in developing their professional competences. Evans et al. emphasise that learners' life experiences influence and shape the outlooks, motivations and dispositions they bring into their new workplace environments (Evans et al. 2006, p. 82).

\section{The spatial dimension: affordances of space and individual agency}

The significance of space in crossing boundaries and transferring knowledge in a range of contexts has been dealt with in previous research (Kersh et al. 2012). Crossing boundaries between the spaces in which learning, work and leisure occur enables learners to transfer and use their skills and knowledge in a variety of contexts. Lynne Chisholm's (2008) research employs the concept of active learning as a set of differentiated practices revealing close associations with social locations and experiences. In this context, positive associations with a learning space (e.g., the workplace environment) facilitate individual learning attitudes and provide favourable circumstances for skills development. Nicky Solomon et al. (2006) emphasise the associations between space and learning and their importance for understanding social relations, specifically in the context of workplace learning. Thus, the workplace becomes an important arena for acquiring skills and culture, in addition to being a place of employment and income (Rismark and Sitter 2003).

The learners' spaces, contexts and environments, whether immediate or indirect, provide circumstances for learning which could be situated, as noted by Evans et al. (2006), in three ways: in practical activity; in the culture and the context of workplace/learning environments; and in the socio-biographical features of the learner's life, where the learning spaces and environments are not necessarily physical places but configurations of the person's biography, experiences and life 
trajectory. Therefore, as considered above, space is not necessarily understood as physical space (such as a classroom or workshop). The idea of the learning space at work is much more complex and broad. It is associated with social practices or social institutions, such as workplaces, which are different from those linked to a traditional school or college educational delivery. Learning space is therefore perceived as a context which facilitates learning, not necessarily in a specific physical space (Kersh et al. 2012). Our empirical work has similarly indicated that employees perceive the notion of the learning space as a broad concept, which goes beyond the conventional classroom and includes workplace locations, libraries, meeting rooms and a range of other formal and informal environments, including virtual spaces. Spatial associations may either facilitate or undermine employee motivation to acquire skills within specific learning spaces. Our interviews exploring basic skills acquisition in the workplace indicated that employees feel motivated to acquire skills in their workplace spaces, as they feel that these skills are specifically relevant to their job roles. As noted by a Social Care worker:

Yes, because I've got to learn writing things down and, you know, information that you have to write in files. I think English will be useful. [...] because the tenants have, like, yellow files in all the flats and so you write in them how that person is that morning, the medication you give them, personal care all goes down, so that they have that information. It's basically [...] you're required to write an observation, what's happened and [...] And, like, say if they've had a fall then they look and say "oh such and such had a fall, we're waiting for a doctor coming out", it's all written down in there in their little file. So writing skills are most useful (Extract from employee interview, Skills for Life project).

Conversely, some learning spaces have negative connotations, and as a result contribute to demotivating individuals and undermining their learning attitudes. Some respondents cited their precious negative associations with learning in formal education settings (for example schools or colleges) as significantly undermined their motivation to engage in learning activities:

yes, it's nothing like being back at school at all. At school I did not like it, they were very strict and unfriendly, and I was not confident. I did not like maths and I did not like English [...] because I could not understand, and no one helped me (Extract from employee interview, Skills for Life Project).

Being in a learning space where individuals feel confident exercising their agency through participation and recognition significantly enhances the motivation to learn. What is more, findings indicate that the interplay of individual biographies, dispositions and attitudes of learners with the potential utility of workplace environments may further facilitate or undermine motivation and learning success within workplace spaces (Evans et al. 2006). In addition, it encourages individuals to navigate new spaces, where they can apply skills acquired through a range of activities and in a range of spaces.

Another fundamental facet of knowledge transfer and boundary crossing is the development of VLEs which allow learners to extend their learning spaces to a 
variety of new spaces, including home and workplace spaces. Digital technologies provide learners with opportunities to access and engage in learning activities in a range of related contexts, including home, college and workplace environments, public libraries and youth centres. Computer literacy and IT skills have contributed to the development of the virtual learning space where learning may not be associated with a specific site or time, and this provides a degree of flexibility for the learners, enabling them to acquire learning at a time and place convenient for them. The use of new technologies and mobile learning has gradually changed approaches to and ways of teaching and learning within the context of vocational education and training (VET), making it easier for learners to cross boundaries between spaces.

\section{Organisational dimension: affordances provided by employers or training providers}

The extent to which employees and learners may apply and transfer their skills and knowledge across boundaries and contexts is often integral to the organisational dynamic in the workplace or place of learning for a qualification (e.g., Further Education [FE] college). The organisational context which facilitates the process of boundary crossing involves opportunities and potential utility which learners/ employees may access as a result of schemes and arrangements offered by employers or colleges (or other places of learning).

The notion of expansive-restrictive environments (Fuller and Unwin 2011) relates to the potential affordances of the workplace, where organisational and sectoral conditions influence both workplace opportunities and employees' perceptions at work. Making a workplace a learning space has been considered one of the challenges of contemporary workplace development. Support for the continuous competence development of employees is one of the factors that facilitates the learning workplace. Work-related competences are now increasingly considered in a broader sense, rather than focusing exclusively on narrowly defined tasks. Individuals are now expected to avail of a range of competences, including personal skills, and be able to apply these as they move between changing contexts, both within and outside their workplaces. The development of work-related competences is strongly influenced by the complexities of learning spaces, including the virtual learning space. As digital technologies have developed, workplace learning has encompassed digital skills. The exercise of human agency through the virtual environment has the potential to facilitate learning at work, relating it to other spaces and environments. The empirical work has identified the following arrangements/strategies which are perceived as those contributing to boundary crossing and knowledge transfer across different learning contexts: (1) training provider-employer links and partnerships; (2) opportunities for professional and skills development in the workplace (e.g., offering courses for professional or personal development within the workplace; and (3) enhancing teaching and learning arrangements through tailoring to the needs of local industry.

Employment affordances, defined by Evans et al. (2006) as "learning through the workplace" are demonstrated by offering courses and developmental opportunities 
for employees which enable them to cross the spatial boundaries and broaden their interpretation and perception of the workplace space; i.e., perceiving the workplace not just as a site for work or organisation-specific training but as a space which enables them to learn and acquire new skills that can be used in a range of contexts. Interviews undertaken as part of the "Skills for Life" project indicate that, for some employees, acquiring or developing relevant basic skills within the workplace facilitated competence development (personal or professional) through a range of affordances and life experiences. The research has identified the link between the "Skills for Life" courses and employee motivations and attitudes, specifically related to developing capabilities to apply literacy and numeracy skills in a range of contexts, thus crossing the boundaries between different spaces. Employee engagement in the "Skills for Life" programmes in the workplace illustrates the interplay between various configurations of the learning space. Literacy and numeracy courses in the workplace challenge traditional perceptions of the workplace as a location designated exclusively for performing work activities. At the same time, acquiring a range of "skills for life" enabled employees to use them in other contexts, for example in their home environments. The interdependencies and interplay in learning between the different contexts are underpinned, in part, by the development of "skills for life" acquired through workplace-located courses.

\section{Conclusions}

Different implications and configurations of the learning space at work facilitate the achievement of agency by providing opportunities and affordances for the development of personal skills, motivations and outcomes in a range of contexts and setting. In this paper I have discussed a number of implications and perceptions of learning through boundary-crossing experiences, considering them in terms of three dimensions: individual (role of an individual), spatial (the potential utility of a space) and organisational (opportunities provided by an organisational context). Individual motivation, skills development and institutional context strongly relate to the interplay of actors, spaces and learning processes. This interplay is not restricted to the workplace but involves the overlap of learning spaces and other contexts which extend far beyond the workplace. Employees' perceptions and attitudes are shaped by social structures facilitating their engagement, motivation and life chances within the learning spaces and beyond.

This research suggests that learning through boundary crossing within and between the contexts of education, work and other spaces is related to a range of dimensions; individual, spatial and organisational. Within these dimensions, the interplay between learning and work spaces has been characterised by somewhat blurred boundaries, making those spaces multifaceted and multidimensional. Learning through "boundary crossing" contributes to an understanding of learning at work and the ways in which learners acquire and use knowledge and skills across different contexts.

Crossing boundaries across a range of spaces at work, such as physical, virtual or informal, enables employees to navigate these spaces while learning and using their 
skills within their environments. The learning space is often perceived as a combination or overlap of a range of components, such as physical space, learning contexts and environments, formal/informal learning and virtual learning. Research suggests that engaging in learning and applying skills not only within but across a variety of contexts and spaces enables employees to develop a range of transferrable skills required by the contemporary economy and knowledge society. The interrelations between the individual, spatial and organisational dimensions have been demonstrated by the way in which individuals navigate their workplace spaces, and the extent to which these environments may enhance attitudes, motivations and occupational and learning careers. Developing motivations and individual engagement in the workplace is one of the factors that facilitates the learning organisation at work. Individuals are now increasingly expected to use a range of skills (both tacit and explicit), and be able to apply these skills as they move between changing spaces and contexts. The exercise of agency through using different types of knowledge across different spaces has the potential to facilitate learning and skills development at work, and the complexities of workplace learning which shape employees' perceptions and attitudes towards engagement and motivation have been reflected in the changing requirements for skills development and the changing nature of the learning space at work.

Open Access This article is distributed under the terms of the Creative Commons Attribution 4.0 International License (http://creativecommons.org/licenses/by/4.0/), which permits unrestricted use, distribution, and reproduction in any medium, provided you give appropriate credit to the original author(s) and the source, provide a link to the Creative Commons license, and indicate if changes were made.

\section{References}

Akkerman, S., \& Bakker, A. (2011). Learning at the boundary: An introduction. International Journal of Educational Research, 50(1), 1-5.

Aspin, D., Chapman, J., Evans, K., \& Bagnall, R. (Eds.). (2012). The second international handbook of lifelong learning. Dordrecht: Springer.

Bakker, A., Kent, P., Hoyles, C., \& Noss, R. (2011). Designing for communication at work: A case for technology-enhanced boundary objects. International Journal of Educational Research, 50(1), 26-32.

Billet, S. (2011). Subjectivity, self and personal agency in learning through and for work. In M. Malloch, L. Cairns, K. Evans, \& B. N. O’Connor (Eds.), The Sage handbook on workplace learning (pp. 60-72). Thousand Oaks, CA: Sage.

Boud, D. (2006). Combining work and learning: The disturbing challenge of practice. In R. Edwards, J. Gallagher, \& S. Whittaker (Eds.), Learning outside the academy: International research perspectives on lifelong learning (pp. 77-89). London: Routledge.

Boud, D., Keogh, R., \& Walker, D. (Eds.). (1985). Reflection. Turning experience into learning. London/ New York: Routledge.

Bronfenbrenner, U. (1977). Toward an experimental ecology of human development. American Psychologist, 32(7), 513-530.

Brooks, R., Fuller, A., \& Waters, J. (Eds.). (2012). Changing spaces of education: New perspectives on the nature of learning. London: Routledge.

Burrough, P. A. (1996). Natural objects with indeterminate boundaries. In P. A. Burrough \& A. U. Frank (Eds.), Geographic objects with indeterminate boundaries (pp. 3-28). London: Taylor and Francis. 
Chisholm, L. (2008). Re-contextualising learning in second modernity. Research in Post-Compulsory Education, 13(2), 139-147.

Ecclestone, K., Biesta, G., \& Hughes, M. (Eds.). (2009). Transitions and learning through the lifecourse. London: Routledge.

Edwards, A. (2011). Building common knowledge at the boundaries between professional practices: Relational agency and relational expertise in systems of distributed expertise. International Journal of Educational Research, 50(1), 33-39.

Edwards, R., Gallagher, J., \& Whittaker, S. (Eds.). (2004). Learning outside the academy: International research perspectives on lifelong learning. London: Routledge.

Engeström, Y., Engeström, R., \& Karkkainen, M. (1995). Polycontextuality and boundary crossing in expert cognition: Learning and problem solving in complex work activities. Learning and Instruction, 5(4), 319-336.

Engeström, Y., Engeström, R., \& Kärkkäinen, M. (1997). The emerging horizontal dimension of practical intelligence: Polycontextuality and boundary crossing in complex work activities. In R. J. Sternberg \& E. Grigorenko (Eds.), Intelligence: Heredity and environment (pp. 440-462). Cambridge: Cambridge University Press.

Eraut, M. (2004). Informal learning in the workplace. Studies in Continuing Education, 26(2), $247-273$.

Eraut, M., \& Hirsh, W. (2007). The significance of workplace learning for individuals, groups and organisations. Oxford/Cardiff: ESRC Centre on SkilIs, Knowledge and Organisational Performance (SCOPE). Available at http://www.skope.ox.ac.uk/wordpress/wp-content/uploads/2014/12/Monogrpah09.pdf. Accessed 25 May 2015.

Evans, K., Guile, D., \& Harris, J. (2011). Rethinking work-based learning: For education professionals and professionals who educate. In M. Malloch, L. Cairns, K. Evans, \& B. N. O'Connor (Eds.), The Sage handbook of workplace learning (pp. 149-161). Thousand Oaks, CA: Sage.

Evans, K., Hodkinson, P., Rainbird, H., \& Unwin, L. (2006). Improving workplace learning. New York: Routledge.

Evans, K., \& Kersh, N. (2014). Training and workplace learning. In K. Kraiger, J. Passmore, N.-R. Santos, \& S. Malvezzi (Eds.), The Wiley-Blackwell handbook of the psychology of training, development and performance improvement (pp. 50-67). Chichester: Wiley.

Evans, K., Kersh, N., \& Kontiainen, S. (2004). Recognition of tacit skills: Sustaining learning outcomes in adult learning and work re-entry. International Journal of Training and Development, 8(1), 54-72.

Evans, K., Waite, E., \& Kersh, N. (2011). Towards a social ecology of adult learning in and through the workplace. In M. Malloch, L. Cairns, K. Evans, \& B. N. O’Connor (Eds.), The Sage handbook on workplace learning (pp. 356-370). Thousand Oaks, CA: SAGE Publications Ltd.

Foucault, M. (1980). Power/knowledge. Selected interviews and other writings 1972-1977. New York: Pantheon.

Fuller, A., \& Unwin, L. (2011). Workplace learning and the organization. In M. Malloch, L. Cairns, K. Evans, \& B. N. O'Connor (Eds.), The Sage handbook on workplace learning (pp. 46-59). Thousand Oaks, CA: Sage.

Gatrell, A. C. (1991). Concepts of space and geographical data. In D. J. Maguire, M. F. Goodchild, \& D. W. Rhind (Eds), Geographical information systems: Principles and applications, vol. 1 (pp. 119-134). Harlow/New York: Longman/John Wiley \& Sons Inc.

Gibson, J. J. (1977). The theory of affordances. In R. Shaw \& J. Bransford (Eds.), Perceiving, acting, and knowing: Toward an ecological psychology (pp. 67-82). Hillsdale, NJ: Erlbaum.

Gibson, J. J. (1979). The ecological approach to visual perception. Boston, MA: Houghton Mifflin.

Gnaur, D. (2010). Seizing workplace learning affordances in high-pressure work environments. Vocations and Learning, 3(3), 223-238.

Goffman, E. (1990). The presentation of self in everyday life. London: Penguin.

Guile, D. (2010). The learning challenge of the knowledge economy. Rotterdam: Sense.

Harreveld, B., \& Singh, M. (2009). Contextualising learning at the education-training-work interface. Education \& Training, 51(2), 92-107.

Harris, R., \& Ramos, C. (2012). "The one less travelled": Adult learners moving from the academic sector to the vocational sector in Singapore and Australia. Journal of Vocational Education \& Training, 64(4), 387-402.

Hodkinson, P. (1995). Professionalism and competences. In P. Hodkinson \& M. Issit (Eds.), The challenge of competence: Professionalism through vocational education and training (pp. 58-69). London: Cassell. 
Hodkinson, P., Hodkinson, H., Evans, K.,\& Kersh, N. with Fuller, A., Unwin, L., \& Senker, P. (2004). The significance of individual biography in workplace learning, Studies in the Education of Adults, 36(1), 6-24.

Kersh, N., Evans, K., \& Kontiainen, S. (2011). Use of conceptual models in self-evaluation of personal competences in learning and in planning for change. International Journal of Training and Development, 15(4), 290-305.

Kersh, N., Waite, E., \& Evans, K. (2012). The spatial dimensions of workplace learning: acquiring literacy and numeracy skills within the workplace. In R. Brooks, A. Fuller, \& J. Waters (Eds.), Changing spaces of education: New perspectives on the nature of learning (pp. 182-204). London: Routledge.

Kohlegger, M., Maier, R. \& Remus, U. (2013). Freedom of choice: Perspectives on personal workplaces. Proceedings of the 21st European Conference on Information Systems ECIS 2013, Utrecht, Netherlands. Available at http://www.staff.science.uu.nl/ vlaan107/ecis/files/ECIS2013-0166paper.pdf, Accessed 9 November 2015.

Kolb, D. A. (1984). Experiential learning. Englewood Cliffs, NJ: Prentice Hall.

Kolb, A., \& Kolb, D. (2005). Learning styles and learning spaces: Enhancing experiential learning in higher education. Academy of Management Learning \& Education, 4(2), 193-212.

Lave, J., \& Wenger, E. (1998). Communities of practice: Learning, meaning, and identity. Cambridge: Cambridge University Press.

Malloch, M., Cairns, L., Evans, K., \& O’Connor, B. N. (Eds.). (2011). The Sage handbook of workplace learning. Thousand Oaks, CA: Sage.

Pidwirny, M. (2006). Concepts of time and space in physical geography. In Fundamentals of physical geography, section c) in chapter 3, The science of physical geography (online resource). 2nd edn. Available at http://www.physicalgeography.net/fundamentals/3c.html. Accessed 9 November 2015.

Rainbird, H., Fuller, A., \& Munro, A. (Eds.). (2004). Workplace learning in context. London: Routledge.

Rismark, M., \& Sitter, S. (2003). Workplaces as learning environments: Interaction between newcomer and work community. Scandinavian Journal of Educational Research, 47(5), 495-510.

Soja, E. (2002). Postmetropolis, critical studies of cities and regions (4th ed.). Oxford/Malden, MA: Blackwell.

Solomon, N., Boud, D., \& Rooney, D. (2006). The in-between: Exposing everyday learning at work. International Journal of Lifelong Education, 25(1), 3-13.

Tuomi-Grohn, T., \& Engeström, Y. (2003). Between school and work: New perspectives on transfer and boundary crossing. Oxford: Pergamon.

Young, M., Tuomi-Gröhn, T., \& Engeström, Y. (2003). From transfer to boundary-crossing between school and work as a tool for developing vocational education: An Introduction. In T. Tuomi-Gröhn \& Y. Engeström (Eds.), Between school and work: New perspectives on transfer and boundary crossing (pp. 1-19). Oxford: Pergamon (Elsevier Science).

\section{The author}

Natasha Kersh Ph.D., is researcher and lecturer at the Department of Education, Practice and Society, UCL Institute of Education, University of London. Natasha is an experienced researcher with 12 years of experience in exploring various aspects of education and lifelong learning, in both national (UK-based) and European contexts. Her research interests and publications relate to the study of workplace learning in the UK and international contexts as well as comparative education, lifelong learning, and vocational education and training. 